\title{
Allerjik Rinit Hastalarımızda Alerji Testleri
}

\author{
Allergy Tests in Allergic Rhinitis Patients \\ Zübeyde DİNÇER ${ }^{1}$, Mehmet Yaşar ÖZKARS²
}

${ }^{1}$ Ar. Gör. Dr. Kahramanmaraş Sütçü İmam Üniversitesi Tip Fakültesi, Çocuk Sağlığı ve Hastalıkları Anabilim Dalı, KAHRAMANMARAŞ

${ }^{2}$ Dr. Öğ. Üyesi, Kahramanmaraş Sütçü İmam Üniversitesi Tip Fakültesi, Çocuk İmmünolojisi ve Allerji Bilim Dalı, KAHRAMANMARAŞ

\section{Öz}

Giriş: Alerjik Rinit (AR) çeşitli semptomlarla görülen (boğazda veya burunda kaşıntı ve hapşırma) mevsimsel ya da yıl boyu olabilen, yaygın bir hastalıktır. Alerjik rinit tanısı ayrıntılı anamnez, fizik muayene ve laboratuar testleriyle konulmaktadır. Laboratuarda alerji deri testi, serum total IgE, serum spesifik IgE düzeyi, nazal salgıların incelenmesi tanıya yardımcıdır.

Yöntem: Çalışmamızda AR tanılı 52 hasta dosyaları taranarak kan eozinofil sayıları ve yüzdeleri, alerji deri testi sonuçları ve serum alerji spesifik IgE değerleri incelendi. Aynı yaş ve cinsiyette kronik hastalığı olmayan sağlıklı 55 kontrol hastasının ise sadece kan eozinofil sayıları ve yüzdeleri incelendi.

Bulgular: AR tanılı 22 hastada (\% 42,3) eozinofili bulundu. AR ve Kontrol Gruplarının kan eozinofil yüzdesi değerlerinin karşıllaştırılması sonucu istatistiksel olarak anlamlı bulundu ( $\mathrm{p}=0.009)$. AR tanılı hastalar kendi içinde kıyaslandığında 10 hastada serum alerjen spesifik IgE pozitifliği, 10 hastada alerjen ile deri testinde pozitiflik bulundu. Alerji deri testi ve/veya serum spesifik IgE pozitifliği birlikte değerlendirildiğinde 18 hastada (\% 34,6) pozitiflik bulundu.

Sonuç: Çalışmamızın sonucunda eozinofili varlığı AR tanısında alerji testinden daha üstün bulunmuştur.

Anahtar Kelimeler: Alerjik rinit, alerji testleri, eozinofili

\section{Abstract}

Objective: Allergic Rhinitis (AR) is seasonal or year-round, common disease seen with several symptoms (pruritis at throat or nose, sneezing). The diagnosis of allergic rhinitis is made by detailed anamnesis, physical examination and laboratory tests. In the laboratory, skin testing, serum total IgE, specific IgE levels, nasal secretions are helpful in the diagnosis.

Material and Methods: In our study, 52 patients with AR were screened for blood eosinophil counts and percentages, allergy skin test results, and allergy-specific IgE levels. Only blood eosinophil counts and percentages of 55 healthy control patients without chronic disease at the same age and gender were studied.

Results: Eosinophili was found in $22(42.3 \%)$ patients who have AR. The comparison of Eosinophil Percentage values of AR and Control Groups was statistically significant $(p=0.009)$. When AR patients were compared within themselves, allergen-specific IgE positivity was found to be positive in 10 patients, positivity in skin test with allergen in 10 patients, Allergen skin test and calorie specific IgE test in $18(\% 34,6)$ patients were positive.

Conclusion: As a result of our study, eosinophilia was found to be superior to allergy test in AR.

Key Words: Allergic rhinitis, allergy tests, eosinophils

\section{GİRIŞ}

Alerjik Rinit (AR) mevsimsel veya y1l boyu olabilen, boğazda veya burunda kaşıntının yanında hapşurma şikayeti ile kendini gösteren ve sıklığ 1 da yıldan yıla artan bir hastalıktır. Rinitli olguların yaklaşık \% 50'si alerjiktir (1). Alerjik rinitte semptomlar spesifik alerjenlere karşı oluşan immünglobulin E (1gE) aracılı immün yanıt nedeniyle gelişen inflamasyon sonucu ortaya çıkmaktadır. Bu immün yanıt inflamatuar mediatörlerin salınımı ve çeşitli hücrelerin nazal mukozaya göçüne neden olmaktadır (2). Alerjik rinitin klasik olarak 3 tipi vardır; Mevsimsel alerjik rinit, perennial alerjik rinit ve mesleksel alerjik rinit şeklindedir. Alerjik rinit tanısı ayrıntılı anamnez, fizik muayene ve laboratuar testleriyle konulmaktadır. Öyküde semptomların başlangıcı, süresi, mevsimlerle ilişkisi ve aile hikayesi, çevrede hayvan teması olup olmadığı özellikle sorgulanır. Fizik muayenede kronik burun akıntısı ve silme sonucu oluşan burunüstkısmında çizgi, süreklikaşınmahareketi (alerjik selam), alt göz kapağında mor renkli halkalar (alerjik shiners) dikkat çeken bulgulardır. Laboratuarda deri prick testi (DPT), serum total IgE, serum spesifik IgE düzeyi, nazal salgıların incelenmesi tanıya yardımcıdır $(3,4)$. Ayırıcı tanıda enfeksiyonlar, alerjik olmayan rinit, nazal tümörler, sistemik hastalıklar, ilaç kullanımları gibi durumlar düşünülmelidir.

$\begin{array}{ll}\text { İletişim: } & \text { Dr. Zübeyde Dinçer, KSÜ Tıp Fakültesi, Çocuk Sağlığı ve } \\ & \text { Hastalıkları AD, Kahramanmaraş } \\ \text { DOI: } & \mathbf{1 0 . 1 7 5 1 7 / k s u t f d . 4 5 4 4 1 3}\end{array}$

Tedavide alerjenden korunma en önemli basamağ 1 oluşturur. İlaç tedavisinde antihistaminikler, nazal steroidler ve lökotrien reseptör antagonistleri kullanılır. İmmunoterapi, inflamatuar reaksiyonların ve alerjik semptomların önlenmesine yönelik olarak önerilmektedir. Cerrahi tedavi ise anatomik sorunların olduğu durumlarda önerilebilir. AR li hastaların bir kısmında alerji gösterilebilirken, alerji tespit edilemeyen hastalar da mevcuttur. Bazı çalışmalarda astım hastalarında eozinofil yüksekliği gözlenmiştir (5). Astım hastalarında eozinofili birlikteliği olması AR hastalarında da eozinofili birlikteliğini düşündürmektedir. Çalışmamızda alerjik rinit tanılı hastalarda alerji bulunabilme oranını ve eozinofili oranını inceledik. Alerji bulunma oranı ile eozinofili oranını alerjik rinit tanılı hastalarda kıyasladık. Bu oranları aynı zamanda kontrol grubu ile kıyaslayarak anlamlı ilişki olup olmadığını tespit etmeyi amaçladık.

\section{GEREÇ VE YÖNTEM}

AR tanısı ile takipli 52 hastanın dosya taraması yapıldı. İncelemede kan eozinofil sayıları ve yüzdeleri, alerji deri testi sonuçları ve kanda alerji spesifik IgE değerleri incelendi.

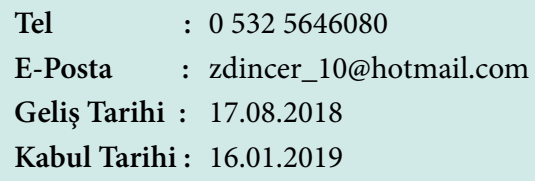


Aynı yaş ve cinsiyette kronik hastalığı olmayan sağlıklı 55 kontrol hastasının ise sadece kan eozinofil sayıları ve yüzdeleri incelendi. Veriler bilgisayar ortamında SPSS 18 paket programı kullanılarak istatistiksel olarak değerlendirildi. Bu değerlerin istatistiksel olarak anlamlı olup olmadı̆̆ İstatistiksel anlamlılık olarak p <0,05 değeri kabul edildi.

\section{BULGULAR}

AR grubunun $(n=52)$ ortalama yaşı (mean \pm standard deviation) $6.48 \pm 3.72$, kontrol grubunun $(n=55)$ ortalama yaşı ise $6.12 \pm 3.58$ olarak bulunmuştur $(\mathrm{p}=0.610)$. AR grubunda K1z/Erkek oran1 20/32 iken kontrol grubunda K1z/Erkek oranı 20/35 olarak tespit edildi (Tablo 1). AR grubu hastalarımızın 22 (\%42.3) tanesinde eozinofili tespit edilebilirken, kontrol grubunda 12 (\%21.1) hastada eozinofili tesbit edilmiştir $(\mathrm{p}=0.014)$. Mutlak eozinofil değerleri incelendiğinde AR grubu (mean \pm standard deviation; 326.73 \pm 225.14 ) olanların, kontrol grubuna (217.72 \pm 151.79$)$ kıyasla daha yüksek eozinofil sayılarına sahip oldukları tespit edilmiştir $(\mathrm{p}=0.002)$ (Şekil 1). Benzer şekilde eozinofil yüzdesi değerleri incelendiğinde AR grubu (3.79 \pm 2.42$)$ olanların, kontrol grubuna $(2.88 \pm 1.57)$ kıyasla daha yüksek eozinofil sayılarına sahip oldukları tespit edilmiştir ( $\mathrm{p}=0.009)$ (Şekil 2). AR tanısı alan hastalarımızın sadece 10 tanesinde (\% 19,2) kanda alerjen spesifik IgE pozitifliği tespit edilebildi. Yine AR olan hastalarımızın sadece10 tanesinde $(\%$ 19,2) alerjen ile deri testinde pozitiflik tespit edilebildi. Alerjen deri testi ve kanda spesifik IgE testi birlikte değerlendirildiğinde ise 18 hastada (\% 34,6) alerji pozitifliği bulundu. Olgularımızın demografik özellikleri ve eozinofil değerleri Tablo 1'de gösterilmiştir.

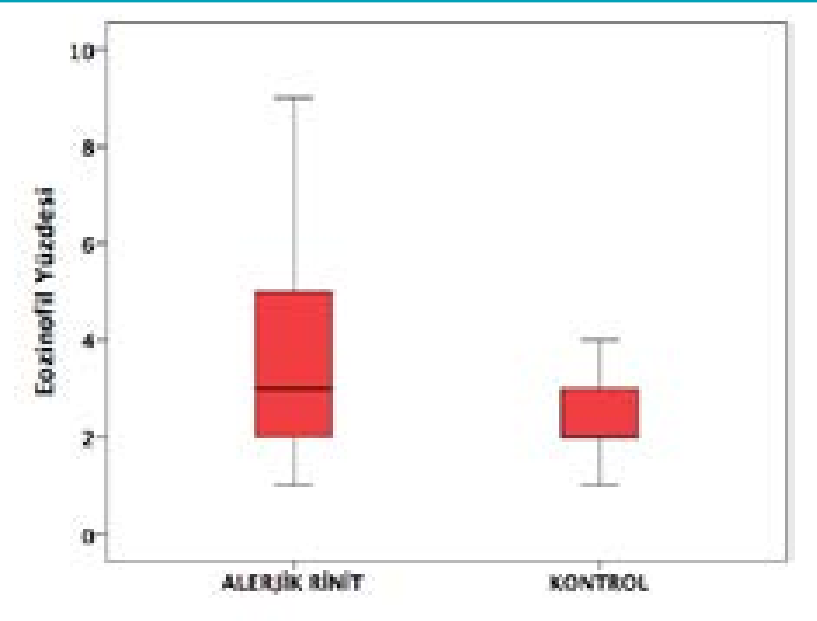

Şekil 2. AR ve kontrol Gruplarının Eozinofil Yüzdesi değerlerinin karşılaştırılması $(p=0.009)$.

\section{TARTIŞMA}

Alerji testleri, alerjik hastalıkların tanı ve takibinde, alerjenden korunma şekillerinin belirlenmesinde, spesifik tedavilerin seçilmesinde (ilaç, immünoterapi gibi) ve erken tanı gibi durumların belirlenmesinde kullanılmaktadır (6).

Klinikte kullanılan alerji testleri temel olarak ikiye ayrilır. Bunlar hasta üzerinde uygulanan (in vivo: deri testleri, yama testi, provakasyon testleri) ve hastadan alınan örneklerde bakılan (in vitro: eozinofil sayımı, immunglobulin E, spesifik IgE ve bazofil aktivasyon testleri) testlerdir (7).

Çalışmamızda her iki yöntem de kullanılmıştır.

Tablo 1. Olgularımızın demografik özellikleri ve eozinofil değerlerinin gösterimi

\begin{tabular}{|l|l|l|l|}
\hline & AR Grubu (n:52) & Kontrol Grubu $(n: 55)$ & $p$ \\
\hline Yaş (yal)* & $6.48 \pm 3.72$ & $6.12 \pm 3.58$ & 0.6101 \\
\hline Cinsiyet (kız/erkek) & $20 / 32$ & $20 / 35$ & 0.5732 \\
\hline Eozinofil \% & $3.79 \pm 2.42$ & $2.88 \pm 1.57$ & 0.0093 \\
\hline Mutlak Eozinofil Sayısı & $326.73 \pm 225.14$ & $217.72 \pm 151.79$ & 0.0023 \\
\hline Eozinofili Varlı̆̆ $n$ (\%) & $22(\% 42.3)$ & 0.0142 \\
\hline${ }^{*}$ mean \pm standard deviation, 1One-Way Anova Test, 2 Chi-square Test, 3 Independent Samples t Test \\
\hline
\end{tabular}

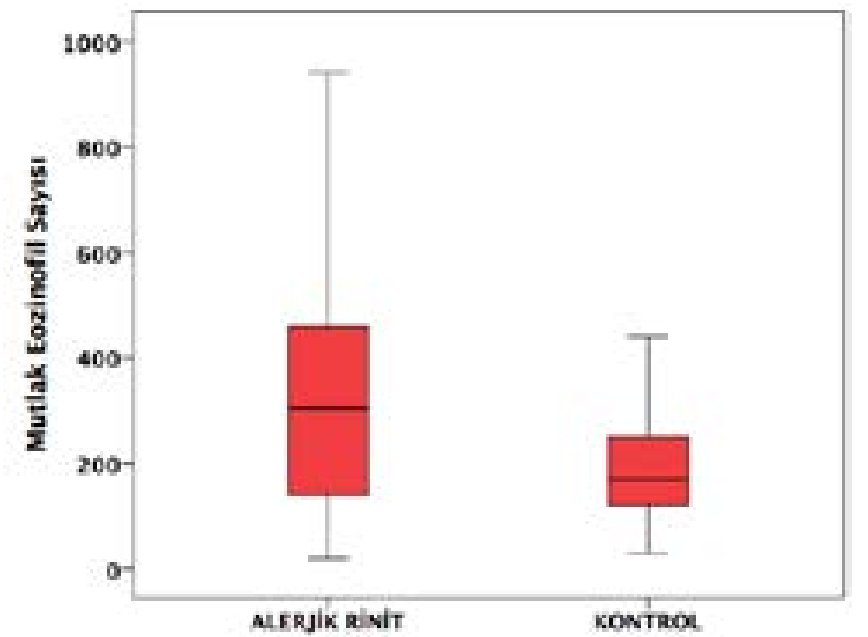

Şekil 1. AR ve kontrol gruplarının mutlak eozinofil değerlerinin karşılaştırılması $(p=0.002)$.
AR grubu hastalarımızın \% 42.3'ünde eozinofili tespit edilebilirken, kontrol grubunda \% 21.1 hastada eozinofili tespit edilmiştir. AR tanısı alan hastalarımızın \% 19,2 sinde kanda alerjen spesifik IgE pozitifliği tespit edilebildi. Yine AR olan hastalarımızın \% 19,2 sinde alerjen ile deri testinde pozitiflik tespit edilebildi. Alerjen deri testi ve kanda spesifik IgE testi birlikte değerlendirildiğinde ise \% 34,6 hastada alerji pozitifliği bulundu.

Diyarbakır Üniversitesinde yapılan benzer bir çalışmada astımlı hastalar ele alınmış. Total IgE ve kan eozinofil düzeyleri arasında korelasyon incelenmiş. IgE ve eozinofili düzeyleri karşılaştırıldığında hasta grupta eozinofil $\% 4.8 \pm 4.2$ kontrol grubunda ise \% $2.1 \pm 1.0$ olarak bulunmuş. Yine bu gruplar arasında kanda IgE karşılaştırıldığında hasta grupta IgE $378.8 \pm 377.7 \mathrm{IU} / \mathrm{ml}$ iken kontrol grubunda ise $78.5 \pm 62.5 \mathrm{IU} / \mathrm{ml}$ olarak bulunmuş. Yani hasta ve kontrol grubu karşılaştırıldığında her iki parametre için oluşan fark 
istatistiksel olarak anlamlı bulunmuş (8). Astımın tanısı ve ayırıcı tanısında IgE seviyesi ve eozinofil seviyelerinin önemli olması benzer temellere sahip olan hastalıklar içinde yol göstericidir ve bizim çalışmamızı da desteklemektedir.

Yeni Zelanda'da yapılan bir çalışmada 714 atopik çocukta DPT pozitifliği \%46 olarak bulunmuştur (9). İsveç’te yapılan bir başka çalışmada ise astım ve/veya rinokonjunktiviti olan çocuklarda DPT pozitifliği \%43 olarak bulunmuştur (10). Bu çalışmaların çoğunda deri testlerinin \%50'nin altında olması deri testlerinin spesifikliğini tartışmalı yapmakta, tanıda IgE ve eozinofil yüksekliğinin önemini desteklemektedir.

Sonuç olarak AR hastalarının kan eozinofil değerleri kontrol grubundan yüksek bulunmuştur. Ayrıca AR olanların kanında eozinofili tespit edilme oranları alerji tespit edilme oranlarından daha yüksektir. Bu durumda eozinofili varlığ AR tanısında alerji testinden daha üstün gibi görünmektedir. İmmünoterapi endikasyonu olmayan hastalara alerji deri testi yapmaksızın tedavi verilmesi düşünülebilir. Ancak tedavi ile yeterli klinik rahatlama olmayan hastalara immünoterapi açısından alerji testi yapılması düşünülebilir kanaatindeyiz.

\section{KAYNAKLAR}

1. Gentile DA, Shapiro GG, Skoner DP. Allergic rhinitis in pediatric allergy principles and practice eds: leung DYM, Sampson HA, Geha RS, zefler SJ (section E: Leung DYM: upper airway disease) chapter :28 St Louis Mosby 2003, 287-297.

2. Skoner DP. Allergic rhinitis: definition, epidemiology, pathophysiology, detection, and diagnosis. J Allergy Clin Immunol 2001:108:2-8.

3. Akçakaya N, Kulak K, Hassanzadeh A, Camcioglu Y, Cokugras H. Prevalance of bronchial asthma and allergic rhinitis in İstanbul school children. Eur J Epidemiol. 2000; 16: 693-9.
4. Elmas B, Özdemir Ö. Sensitization prevalence of children with allergic rhinitis for inhalant and food allergens in the province of Sakarya, Turkey. JAREM 2017; 7: 63-9.

5. Topal E, Çatal F, Ermiştekin H, Özdemir R, Karadağ A, Sinanoğlu MS, ve ark. Malatya yöresinde astım ve alerjik rinit tanısı konulan çocukların deri prik testlerindeki aeroalerjen dağılımları. Abant Medical Journal 2014. 3: 215-9.

6. Eigenmann PA, Atanaskovic-Markovic M, J O’B Hourihane J, Lack G, Lau S, Matricardi PM et al. Testing children for allergies: why, how, who and when: an updated statement of the European Academy of Allergy and Clinical Immunology (EAACI) Section on Pediatrics and the EAACI-Clemens von Pirquet Foundation. Pediatr Allergy Immunol 2013; 24: 195-209.

7. Frew AJ, Kay AB. Principles and Practice of Diagnosis and Treatment of Allergic Disease. In: Kay AB, Kaplan AP, Bousquet J, Holt PG, eds. Allergy and Allergic Diseases. 2nd ed. Blackwell; 2008. p.13249-514.

8. Tanrikulu AÇ, Dağlı CE, Abakay A, Coşkunsel M. The correlation between total IgE and blood eosinophil level of asthma stages. . 2004; 19: 100-103

9. Sears MR, Herbison GP, Holdaway MD, Hewitt CJ, Flannery EM, Silva PA. The relative risks of sensitivity to grass pollen, house dust mite and cat dander in the development of childhood asthma. Clin Exp Allergy. 1989; 19: 419-24.

10. Norrman E, Rosenhall L, Nyström L, Jönsson E, Stjernberg N. Prevalance of positive skin prick tests, allergic asthma, and rhinoconjunctivitis in teenagers in northern Sweden. Allergy. 1994; 49: 808-15. 